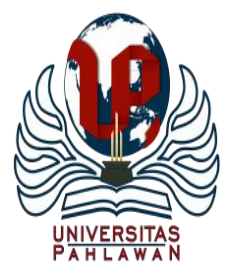

Edukatif : Jurnal Ilmu Pendidikan Volume 3 Nomor 2 Tahun 2021 Halm 355 - 363

EDUKATIF: JURNAL ILMU PENDIDIKAN

Research \& Learning in Education

https:/ledukatif.org/index.php/edukatif/index

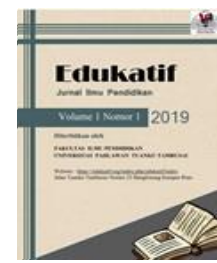

\title{
Pengembangan LKS IPS Berbasis Creative Problem Solving untuk Meningkatkan Kemampuan Berpikir Kreatif Siswa di Sekolah Dasar
}

\author{
Anung Siwi Prabandari ${ }^{1 凶}$, Firosalia Kristin ${ }^{2}$ \\ Universitas Kristen Satya Wacana, Indonesia ${ }^{1,2}$ \\ E-mail : 292017126@ student.uksw.edu ${ }^{1}$ firosalia.kristin@ uksw.edu $^{2}$
}

\begin{abstract}
Abstrak
Penelitian ini dilakukan berdasarkan permasalahan yaitu LKS yang digunakan di sekolah kurang mengembangkan kemampuan berpikir kreatif serta kurangnya bahan referensi. Tujuan penelitian ini untuk mengembangkan produk LKS IPS berbasis model Creative Problem Solving untuk meningkatkan kemampuan dalam berpikir kreatif siswa kelas 4 sekolah dasar, mengetahui tingkat validitas menurut pendapat ahli, dan mengetahui LKS IPS berbasis model Creative Problem Solving yang layak digunakan untuk meningkatkan kemampuan dalam berpikir kreatif siswa kelas 4 sekolah dasar. Produk LKS IPS berbasis Creative Problem Solving berbentuk offline atau hardfile dan online yang dapat diakses melalui website. Penelitian ini menggunakan model pengembangan Borg and Gall yang dimodifikasi dan dikembangkan oleh Sukmadinata yang terdiri dari tiga tahap yaitu: (1) Studi Pendahuluan, (2) Pengembangan Produk, dan (3) Uji Produk. Hasil validasi ahli materi diperoleh skor 70,7\%. Hasil validasi ahli media diperoleh skor $76 \%$. Hasil validasi ahli desain pembelajaran diperoleh skor $77,1 \%$. Skor tersebut dalam kategori tinggi dan LKS IPS berbasis Creative Problem Solving untuk meningkatkan kemampuan berpikir kreatif siswa kelas 4 sekolah dasar layak untuk digunakan.
\end{abstract}

Kata Kunci: LKS IPS, Creative Problem Solving, Kemampuan Berpikir Kreatif Siswa.

\begin{abstract}
This research was conducted based on the problem namely the worksheets used in school did not develop creative thinking skill and lack of reference materials. The purpose of this research was to develop LKS IPS products based on the Creative Problem Solving model to improve the ability to think creatively in grade 4 elementary school students, to determine the validity level according to expert opinion, and knowing the LKS IPS based on the Creative Problem Solving model which is feasible to be used to improve the creative thinking skills of grade 4 elementary school students. LKS IPS products are based on Creative Problem Solving in the form of offline or hardfile and online which can be accessed through the website. This research uses the Borg and Gall development model which is modified and developed by Sukmadinata which consists of three stages, namely: (1) Preliminary Study, (2) Product Development, and (3) Product Testing. The results of the material expert validation obtained a score of 70,7\%. The results of the media expert validation obtained a score of $76 \%$. The results of the learning design expert validation obtained a score of 77,1\%. The score is in the category high and LKS IPS products based on the Creative Problem Solving model to improve the ability to think creatively in grade 4 elementary school students is feasible to use.
\end{abstract}

Keywords: LKS IPS, Creative Problem Solving, Students' Creative Thinking Ability.

Copyright (c) 2021 Anung Siwi Prabandari, Firosalia Kristin

$\triangle$ Corresponding author

Email :292017126@student.uksw.edu

DOI : https://doi.org/10.31004/edukatif.v3i2.309

ISSN 2656-8063 (Media Cetak)

ISSN 2656-8071 (Media Online)

Edukatif : Jurnal Ilmu Pendidikan Vol 3 No 2 Tahun 2021 p-ISSN 2656-8063 e-ISSN 2656-8071 
356 Pengembangan LKS IPS Berbasis Creative Problem Solving untuk Meningkatkan Kemampuan Berpikir Kreatif Siswa di Sekolah Dasar - Anung Siwi Prabandari, Firosalia Kristin

DOI: https://doi.org/10.31004/edukatif.v3i2.309

\section{PENDAHULUAN}

Sumber daya manusia yang dapat membangun masyarakat adalah individu yang terdidik melalui sekolah. Pendidikan formal yang mendasari pada jenjang pendidikan menengah adalah sekolah dasar. Menaruh dasar kecerdasan, kepribadian, akhlak mulia dan keterampilan sehingga siswa dapat hidup mandiri serta mengenyam pendidikan lanjutan yaitu tujuan dari sekolah dasar (Subawa, 2016). Hal tersebut sesuai dengan dilaksanakannya kurikulum 2013 atau sering dikenal dengan istilah K-13. Pendekatan saintifik digunakan pada pembelajaran kurikulum 2013. Terdapat lima aktivitas dalam pendekatan saintifik terdiri dari mengamati, menanya, mencoba atau mengumpulkan data, mengasosiasi dan mengkomunikasikan (Azhar, 2013). Berdasarkan Permendikbud diatas, yang harus dilakukan dalam mengimplementasikan kurikulum 2013 adalah dengan meningkatkan kualitas proses pembelajaran di kelas, karena inti dari peningkatan mutu pendidikan adalah meningkatnya mutu pelaksanaan proses pembelajaran di kelas. Dalam proses kegiatan belajar mengajar, siswa diminta melakukan kegiatan yang terintegrasi antara fisik dan mental demi tercapainya tujuan dalam pembelajaran. Kegiatan belajar mengajar bisa tercipta secara menyenangkan, aktif, kreatif, dan inovatif memerlukan bahan ajar yang mendukung. Lembar kerja siswa merupakan salah satu bahan ajar yang dapat digunakan.

Menurut pengamatan peneliti, LKS yang diberikan kepada siswa hanya berupa deskripsi materi dan soal latihan yang kurang menarik sehingga siswa malas untuk mengerjakannya. Sejalan dengan studi pendahuluan yang dilakukan terhadap beberapa guru SD di lingkungan sekitar serta SD Negeri Mangunsari 04 Salatiga ditemukan fakta bahwa dalam pembelajaran IPS, LKS yang digunakan masih memiliki banyak kekurangan dan keterbatasan. LKS kurang mengembangkan kemampuan berpikir kreatif. LKS hanya mengembangkan kemampuan kognitif siswa pada tingkat rendah. Kurangnya bahan referensi, maka sulit untuk menghasilkan LKS yang dirancang untuk mengembangkan kemampuan berpikir kreatif. Berdasarkan permasalahan yang ditemukan, hal ini menyebabkan siswa kurang memiliki kemampuan berpikir kreatif. Kebiasan berpikir kreatif belum dibiasakan di sekolah-sekolah. Sekolah hanya memacu siswa untuk memberikan jawaban yang tepat daripada memacu siswa untuk memunculkan ide-ide yang baru.

Berdasarkan pernyataan-pernyataan di atas, peneliti perlu memberikan kontribusi dengan mengembangkan LKS IPS berbasis Creative Problem Solving untuk meningkatkan kemampuan berpikir kreatif siswa kelas 4 sekolah dasar. Penelitian ini bertujuan untuk mengembangkan produk LKS IPS berbasis model Creative Problem Solving untuk meningkatkan kemampuan dalam berpikir kreatif siswa kelas 4 sekolah dasar, mengetahui tingkat validitas produk menurut pendapat ahli, dan mengetahui LKS IPS berbasis model Creative Problem Solving yang layak digunakan untuk meningkatkan kemampuan dalam berpikir kreatif siswa kelas 4 sekolah dasar.

LKS merupakan alat bantu dalam kegiatan pembelajaran. LKS tentu saja sesuatu yang tidak asing bagi seorang guru karena sebagai alat bantu dalam proses belajar mengajar (Astuti \& Sari, 2017). LKS terdiri atas enam unsur utama meliputi judul, petunjuk belajar, kompetensi dasar (KD), informasi pendukung, tugas atau langkah kerja dan penilaian (Yanti, 2016). IPS adalah bidang studi yang menganalisis masalah sosial dalam masyarakat dengan meninjau dari berbagai aspek kehidupan. Mata pelajaran IPS pada SD terintegrasi antar disiplin ilmu yang ada dalam mata pelajaran IPS, yaitu Sosiologi, Sejarah, Geografi, dan Ekonomi. Dalam sejarah kurikulum di Indonesia, IPS sebagai mata pelajaran yang terungkap sejak kurikulum 1975. Proses pembelajaran diselenggarakan secara interaktif, menyenangkan, menantang, inspiratif, memotivasi siswa untuk berpartisipasi aktif serta memberikan ruang yang cukup bagi prakarsa, kreativitas, dan kemandirian sesuai dengan bakat, minat, kemampuan, dan perkembangan fisik serta psikologis siswa (Yazdi, 2012). Untuk dapat menyelenggarakan proses pembelajaran semacam itu, menggunakan pendekatan saintifik serta model pembelajaran Creative Problem Solving. Model pembelajaran Creative Problem Solving adalah model pengajaran dan keterampilan dalam memecahkan masalah yang diikuti dengan penguatan keterampilan 
(Oktaviani \& Nugroho, 2015). Model pembelajaran Creative Problem Solving berpusat pada keterampilan pemecahan masalah yang disertai dengan adanya penguatan kreatif. Berpikir adalah aktivitas manusia yang mengarah pada penemuan yang memiliki tujuan (Marliani, 2015). Manusia berpikir untuk menemukan pemahaman atau pengertian yang diinginkan. IPS sangat memungkinkan untuk melatih siswa dalam berpikir kreatif, kritis, sistematis, dan inovatif. Hal tersebut dibenarkan oleh Ruseffendi (Susanto, 2017) menjabarkan bahwa manusia memiliki intelegensi yang terdiri dari tujuh kemampuan mental pokok. Empat dari tujuh kemampuan mental tersebut berkaitan dengan pembelajaran IPS, yakni kemampuan tilikan ruang, kemampuan mengobservasi, kecepatan mengamati, dan penalaran. Model pengembangan diperlukan dalam mengembangkan LKS. Fungsi model pengembangan sebagai acuan dalam pengembangan. Penelitian ini akan menggunakan model pengembangan ADDIE dengan alasan dari segi tahap-tahap pengembangan produk, model penelitian dan pengembangan ADDIE dinilai lebih rasional dan lengkap daripada model pengembangan 4D (Puspasari, 2019).

Penelitian terdahulu yang dilakukan oleh Kristanti (2018) menyebutkan bahwa LKS berbasis Creative Problem Solving layak digunakan ditunjukkan dengan validasi yang memiliki kriteria baik dan meningkatkan kemampuan dalam berpikir kreatif siswa. Berdasarkan penelitian terdahulu, peneliti optimis untuk mengembangkan LKS IPS berbasis Creative Problem Solving untuk meningkatkan kemampuan berpikir kreatif siswa kelas 4 Sekolah Dasar. Dalam pengembangan ini, hanya berfokus pada LKS IPS dengan tema 2 selalu berhemat energi, subtema 2 manfaat energi, materi pemanfaatan sumber daya alam. Harapannya pengembangan LKS menggunakan basis model Creative Problem Solving dapat meningkatkan kemampuan siswa dalam berpikir kreatif, mampu memberikan gambaran referensi LKS yang menarik dan memenuhi kriteria sebagai LKS yang baik. LKS yang dikembangkan memiliki kelebihan yakni berbentuk offline atau hardfile dan online yang dapat diakses melalui website.

\section{METODE PENELITIAN}

Penelitian ini akan mengembangkan LKS IPS berbasis Creative Problem Solving sehingga jenis penelitian yang dipilih yaitu penelitian R\&D. Pengembangan ini, hanya berfokus pada LKS IPS dengan tema 2 selalu berhemat energi, subtema 2 manfaat energi, materi pemanfaatan sumber daya alam. LKS IPS Berbasis Creative Problem Solving berbentuk offline atau hardfile dan online yang dapat diakses melalui website. Dalam penelitian ini LKS akan diuji oleh para ahli. Penelitian ini menggunakan model pengembangan Borg and Gall yang dimodifikasi dan dikembangkan yang terdiri dari tiga tahap yaitu: (1) Studi Pendahuluan, (2) Pengembangan Produk, dan (3) Uji Produk (Sukmadinata, 2017). 

Kreatif Siswa di Sekolah Dasar - Anung Siwi Prabandari, Firosalia Kristin DOI: https://doi.org/10.31004/edukatif.v3i2.309

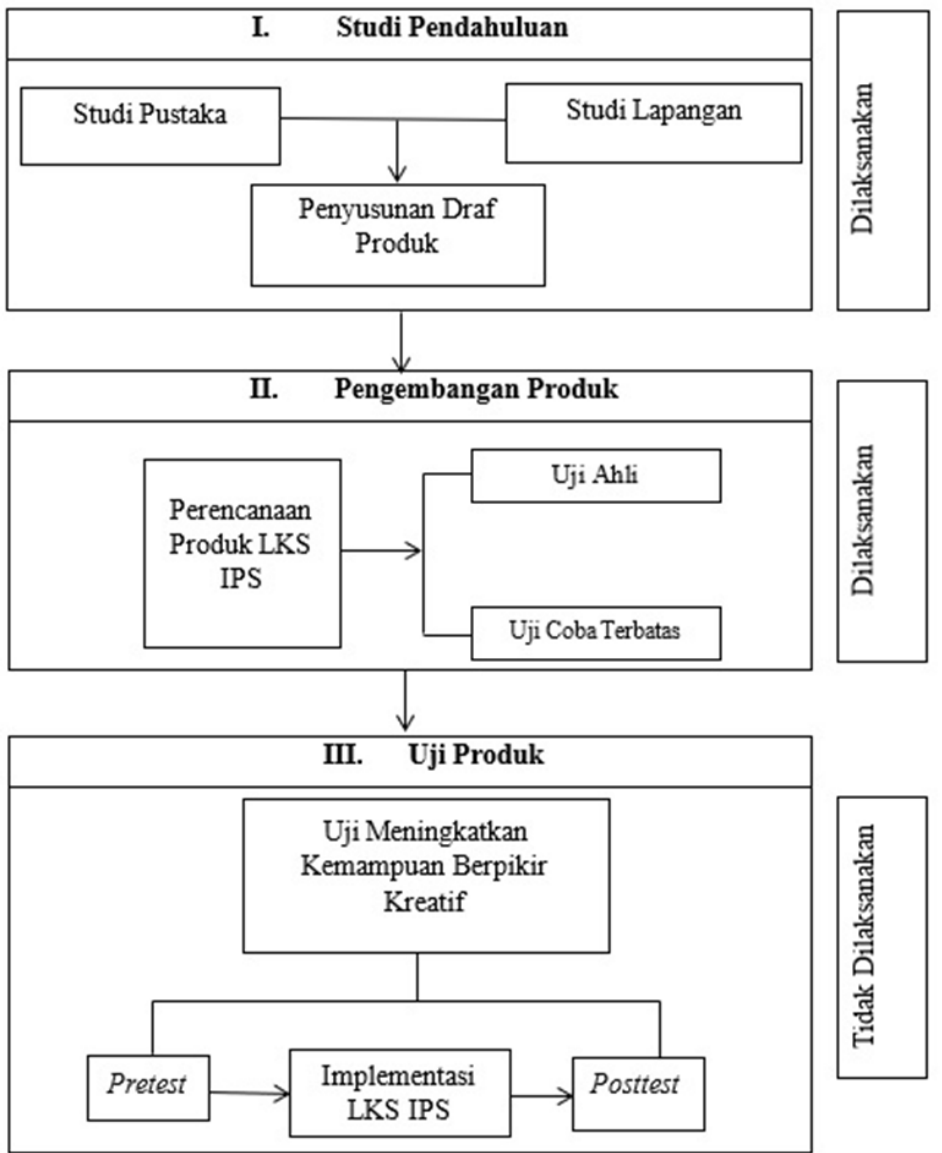

Gambar 1 : Prosedur Penelitian

Berikut tahapan prosedur penelitian pengembangan LKS IPS Berbasis Creative Problem Solving untuk Meningkatkan Kemampuan Berpikir Kreatif Siswa Kelas 4 Sekolah Dasar dapat dilihat pada tabel berikut:

Tabel 1. Prosedur Penelitian

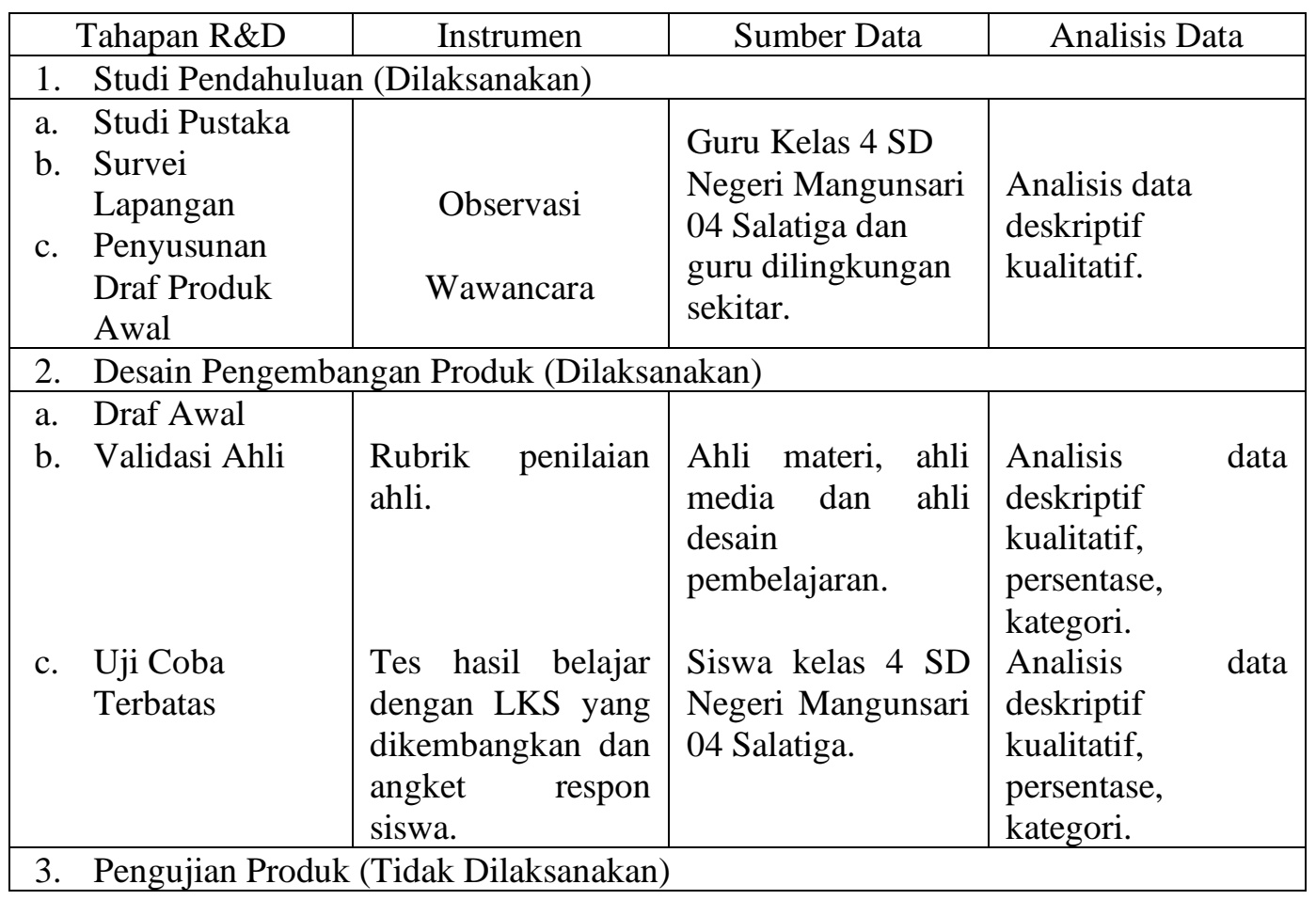


Prosedur penelitian diatas lebih efisien apabila dilaksanakan dengan model pengembangan ADDIE seperti pada gambar berikut:

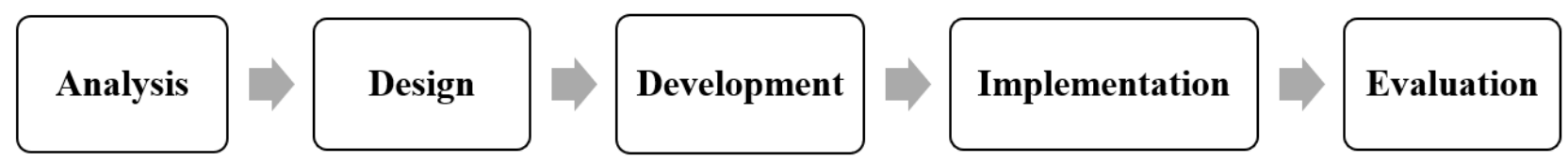

Gambar 2 : Model Pengembangan ADDIE

Deskriptif kualitatif, persentase, dan kategori adalah analisis data yang digunakan untuk mengetahui tingkat validitas dan kelayakan LKS IPS Berbasis Creative Problem Solving untuk Meningkatkan Kemampuan Berpikir Kreatif Siswa Kelas 4 Sekolah Dasar. Hasil skor yang diperoleh dari para ahli dijumlahkan menggunakan rumus berikut:

$$
\mathrm{AP}=\frac{\text { Skor Aktual }}{\text { Skor Ideal }} \times 100 \%
$$

Angka yang diperoleh dan sudah dipersentasekan kemudian dikelompokkan kedalam kategori berikut:

Tabel 2. Kategori Uji Validasi

\begin{tabular}{ll}
\hline Interval & Kategori \\
\hline $81-100 \%$ & Sangat tinggi \\
\hline $61-80 \%$ & Tinggi \\
\hline $41-60 \%$ & Cukup \\
\hline $21-40 \%$ & Rendah \\
\hline $1-20 \%$ & Sangat rendah
\end{tabular}

Hasil uji validasi LKS IPS Berbasis Creative Problem Solving untuk Meningkatkan Kemampuan Berpikir Kreatif Siswa Kelas 4 Sekolah Dasar dapat dinyatakan layak untuk diuji coba bila persentase minimal mencapai kategori tinggi yakni $\geq 61 \%$ (Mawardi, 2014).

Analisis data yang digunakan adalah deskriptif kualitatif, persentase, dan kategori untuk mengetahui LKS IPS Berbasis Creative Problem Solving layak digunakan untuk Meningkatkan Kemampuan Berpikir Kreatif Siswa Kelas 4 Sekolah Dasar. Pada tahap ini dilakukan dengan melihat hasil skor dari angket respon siswa dengan menggunakan rumus berikut:

$$
\mathrm{PK}=\frac{\text { Skor yang diobservasi }}{\text { Skor yang diharapkan }} \times 100 \%
$$

Angka yang diperoleh sudah dipersentasekan kemudian dikelompokkan kedalam kategori (Arikunto, 2014) seperti pada tabel berikut:

Tabel 3. Kategori Kelayakan

\begin{tabular}{ll}
\hline Angka & Kategori \\
\hline $81-100 \%$ & Sangat Layak \\
\hline $61-80 \%$ & Layak \\
\hline $41-60 \%$ & Cukup Layak \\
\hline $21-40 \%$ & Tidak Layak \\
\hline$<21 \%$ & Sangat Tidak Layak \\
\hline
\end{tabular}


Berikut tabel kategori tes hasil belajar siswa dari LKS (Sudijono, 2011) seperti pada tabel berikut:

Tabel 4. Kategori Hasil Belajar Siswa

\begin{tabular}{lll}
\hline Rata-Rata Nilai & Nilai & Kategori \\
\hline 80 ke atas & A & Baik sekali \\
\hline $66-79$ & B & Baik \\
\hline $60-65$ & C & Cukup \\
\hline $46-59$ & D & Kurang \\
\hline 45 ke bawah & E & Gagal \\
\hline
\end{tabular}

\section{HASIL DAN PEMBAHASAN}

Hasil penelitian tentang pengembangan LKS IPS berbasis Creative Problem Solving untuk meningkatkan kemampuan berpikir kreatif siswa kelas 4 sekolah dasar. Berikut penjelasan hasil penelitian tentang pengembangan dengan menggunakan model pengembangan ADDIE. 1) Analisis (Analysis), pada tahap ini dilakukan analisis kebutuhan, kurikulum dan karakteristik siswa dengan teknik observasi dan wawancara yang dilakukan terhadap guru kelas 4 dilingkungan sekitar dan guru SD Negeri Mangunsari 04 Salatiga, mendapatkan informasi bahwa kurikulum yang digunakan yakni kurikulum 2013 yang menggunakan LKS. LKS hanya berupa deskripsi materi dan soal latihan yang kurang menarik sehingga siswa malas untuk mengerjakannya, hanya untuk mengetahui kemampuan kognitif pada tingkat rendah dan sulit menghasilkan LKS yang dirancang untuk mengembangkan kemampuan berpikir kreatif karena kurangnya bahan referensi. 2) Perancangan (Design), pada tahap ini menentukan KD, indikator dan tujuan pembelajaran, menyusun silabus, menyusun RPP, menyusun rancangan LKS. Berikut tampilan produk LKS IPS berbasis Creative Problem Solving:

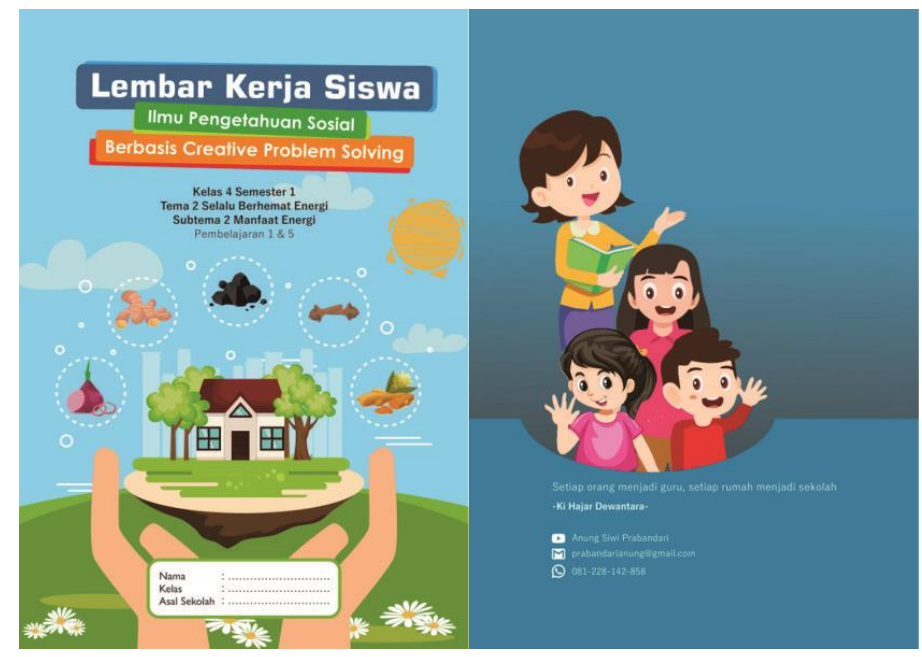

Gambar 3 : Tampilan depan dan belakang LKS

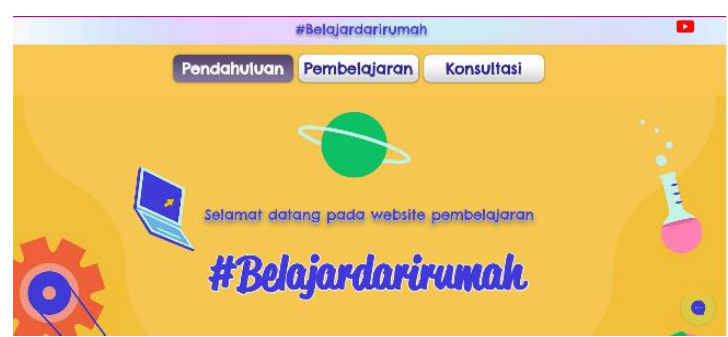

Gambar 4 : Website yang memuat LKS 
3) Pengembangan (Development), pada tahap ini produk yang telah dirancang dan dibuat, divalidasi untuk mengetahui tingkat validitas menurut pendapat 3 ahli yang merupakan dosen dibidang pendidikan. Tingkat validitas LKS IPS berbasis Creative Problem Solving untuk meningkatkan kemampuan berpikir kreatif siswa kelas 4 sekolah dasar menggunakan 3 ahli yang merupakan dosen dalam bidang pendidikan. Berikut hasil tingkat uji validitas LKS IPS berbasis Creative Problem Solving untuk meningkatkan kemampuan berpikir kreatif siswa kelas 4 sekolah dasar seperti pada tabel berikut:

Tabel 5. Hasil Uji Tingkat Validitas menurut Para Ahli

\begin{tabular}{|c|c|c|c|c|}
\hline Validator & $\begin{array}{c}\text { Skor } \\
\text { Ideal }\end{array}$ & $\begin{array}{c}\text { Skor } \\
\text { Aktual }\end{array}$ & Persentase & Kategori \\
\hline Ahli Materi & 140 & 99 & $70,7 \%$ & Tinggi \\
\hline Ahli Media & 125 & 95 & $76 \%$ & Tinggi \\
\hline $\begin{array}{c}\text { Ahli Desain } \\
\text { Pembelajaran }\end{array}$ & 140 & 108 & $77,1 \%$ & Tinggi \\
\hline
\end{tabular}

Hasil uji tingkat validitas menurut ahli materi diperoleh skor 99 dari skor maksimal 140 dengan persentase $70,7 \%$. Validasi oleh ahli materi meliputi aspek kelayakan isi, kebahasaan dan penyajian. Hasil uji tingkat validitas menurut ahli media diperoleh skor 95 dari skor maksimal 125 dengan persentase $76 \%$. Validasi oleh ahli media meliputi aspek kesederhanaan, keterpaduan, penekanan, daya tarik, bentuk dan warna. Hasil uji tingkat validitas menurut ahli desain pembelajaran diperoleh skor 108 dari skor maksimal 140 dengan persentase $77,1 \%$. Validasi oleh ahli desain pembelajaran meliputi aspek komponen LKS, Model Creative Problem Solving, syarat didaktif, syarat konstruksi, dan syarat teknis. Berdasarkan skor yang diperoleh, maka kategori materi, media dan desain pembelajaran pada LKS IPS berbasis Creative Problem Solving untuk meningkatkan kemampuan berpikir kreatif siswa kelas 4 sekolah dasar tergolong dalam interval $61-80 \%$ sehingga termasuk dalam kategori tinggi. Hal ini menunjukkan bahwa hasil uji validasi dapat dinyatakan layak untuk diuji coba karena persentase minimal mencapai kategori tinggi yakni $\geq 61 \%$ (Mawardi, 2014). Walaupun ada yang perlu diperbaiki lagi, LKS IPS berbasis Creative Problem Solving untuk meningkatkan kemampuan berpikir kreatif siswa kelas 4 sekolah dasar layak digunakan.

4) Implementasi (Implementation), pada tahap ini produk di uji coba dalam kelas setelah produk dinyatakan layak oleh para ahli. Uji Kelayakan LKS IPS Berbasis Creative Problem Solving untuk meningkatkan kemampuan berpikir kreatif siswa kelas 4 sekolah dasar melalui uji coba terbatas dapat dilihat dari hasil angket respon siswa dan tes hasil belajar siswa dengan menggunakan LKS yang dikembangkan. Angket respon siswa meliputi aspek kelayakan isi, kebahasaan, penyajian, kegrafikan dan kemanfaatan. Berikut hasil angket respon siswa terkait LKS IPS berbasis Creative Problem Solving untuk meningkatkan kemampuan berpikir kreatif siswa kelas 4 sekolah dasar seperti pada tabel berikut:

Tabel 6. Analisis Angket Respon Siswa

\begin{tabular}{|c|c|c|c|}
\hline No Item & Skor & Frekuensi & Jumlah Skor \\
\hline \multirow{5}{*}{$\begin{array}{c}1,2,3,4,5,6,7,8,9 \\
10,11,12,13\end{array}$} & 5 & 56 & 295 \\
\hline & 4 & 132 & 528 \\
\hline & 3 & 17 & 51 \\
\hline & 2 & 0 & 0 \\
\hline & 1 & 0 & 0 \\
\hline \multicolumn{3}{|c|}{ Jumlah } & 874 \\
\hline \multicolumn{3}{|c|}{ Skor Tertinggi } & 5 \\
\hline \multicolumn{3}{|c|}{ Jumlah Pernyataan } & 13 \\
\hline
\end{tabular}




\begin{tabular}{|c|c|}
\hline Jumlah Siswa & 16 \\
\hline Skor maksimal & 1040 \\
\hline Persentase & $84 \%$ \\
\hline Kategori & Sangat Layak \\
\hline
\end{tabular}

Angket respon siswa meliputi aspek kelayakan isi, kebahasaan, penyajian, kegrafikan dan kemanfaatan. Total jumlah skor dari angket respon siswa yaitu 874 dari skor maksimal 1040 dengan persentase $84 \%$. Hal ini menunjukkan bahwa LKS yang dikembangkan termasuk dalam kategori sangat layak karena berada diantara interval 81-100\% (Arikunto, 2014). Sebanyak 16 siswa SD Negeri Mangunsari 04 Salatiga melaksanakan tes hasil belajar siswa dengan menggunakan LKS yang dikembangkan. Tes hasil belajar siswa dengan menggunakan LKS yang dikembangkan memperoleh nilai rata-rata 86,7. Hal ini menunjukkan bahwa tes hasil belajar siswa dengan menggunakan LKS yang dikembangkan berada pada kategori baik sekali karena nilai rata-rata diatas 80 (Sudijono, 2011). Berikut adalah tes hasil belajar siswa menggunakan LKS yang dikembangkan seperti pada tabel berikut:

Tabel 7. Tes Hasil Belajar Siswa dengan Menggunakan LKS yang Dikembangkan

\begin{tabular}{ccc}
\hline Nilai Akhir & Jumlah Siswa & Kategori \\
\hline 80 ke atas & 11 & Baik Sekali \\
\hline $66-79$ & 5 & Baik \\
\hline $60-65$ & 0 & Cukup \\
\hline $46-59$ & 0 & Kurang \\
\hline 45 ke bawah & 0 & Gagal \\
\hline Jumlah & 16 &
\end{tabular}

Melalui tes hasil belajar siswa diperoleh ketuntasan nilai siswa sebesar 100\%. Dari hasil angket respon siswa dan tes hasil belajar siswa menggunakan LKS yang dikembangkan dinyatakan bahwa LKS IPS berbasis Creative Problem Solving layak digunakan untuk meningkatkan kemampuan berpikir kreatif siswa kelas 4 sekolah.

5) Evaluasi (Evaluation), merupakan tahap akhir dalam penelitian ini. Berdasarkan hasil uji validasi ahli dan uji coba terbatas dapat disimpulkan bahwa LKS IPS berbasis Creative Problem Solving untuk meningkatkan kemampuan berpikir kreatif siswa kelas 4 sekolah dasar layak digunakan oleh siswa. Hal ini relevan dengan penelitian terdahulu yang dilakukan oleh Yulianti (2019) yang menyatakan LKS berbasis Creative Problem Solving dinyatakan sangat valid dengan persentase keidealan 90,67\% menunjukkan bahwa LKS layak untuk digunakan. LKS IPS berbasis Creative Problem Solving memiliki kelebihan berbentuk offline atau hardfile dan online yang dapat diakses melalui website sehingga siswa mudah mengakses dimanapun dan kapanpun. Sedangkan kelemahannya yaitu hanya dilaksanakan sampai uji coba terbatas dengan jumlah 16 siswa dan LKS hanya untuk siswa kelas 4 sekolah dasar dengan materi IPS dengan tema 2 selalu berhemat energi, subtema 2 manfaat energi, pembelajaran 1 dan 5, materi pemanfaatan sumber daya alam.

\section{KESIMPULAN}

Berlandaskan hasil penelitian dan pembahasan dapat disimpulkan bahwa: 1) Langkah-langkah pengembangan yakni analisis, perancangan, pengembangan, implementasi, dan evaluasi. 2) Hasil validasi ahli materi diperoleh skor $70,7 \%$, ahli media diperoleh skor $76 \%$, dan ahli desain pembelajaran diperoleh skor 
$77,1 \%$, skor tersebut termasuk dalam interval $61-80 \%$, jadi tergolong dalam kategori tinggi. 3) Hasil uji coba terbatas berupa tes hasil belajar siswa menggunakan LKS yang dikembangkan diperoleh nilai rata-rata 86,7 dengan kategori baik sekali dan persentase $100 \%$ nilai siswa tuntas. Hasil angket respon siswa diperoleh skor $84 \%$ yang tergolong dalam interval $81-100 \%$, jadi termasuk dalam kategori sangat layak. Dari hasil tersebut diketahui bahwa LKS IPS berbasis Creative Problem Solving untuk meningkatkan kemampuan berpikir kreatif siswa kelas 4 sekolah dasar layak untuk digunakan.

\section{DAFTAR PUSTAKA}

Arikunto, S. (2014). Prosedur Penelitian Suatu Pendekatan Praktik. Jakarta: Rineka Cipta.

Astuti, A., \& Sari, N. (2017). Pengembangan Lembar Kerja Siswa (LKS) pada Mata Pelajaran Matematika Siswa Kelas X SMA. Jurnal Cendekia: Jurnal Pendidikan Matematika, 1(2), 13-24. https://doi.org/10.31004/cendekia.v1i2.16

Azhar. (2013). Penggunaan Pendekatan Saintifik dalam Pembelajaran Tematik di Sekolah Dasar. Pionir: Jurnal Pendidikan, 01(01), 1689-1699.

Kristanti, F., Ainy, C., Shoffa, S., Khabibah, S., \& Amin, S. M. (2018). Developing Creative Problem Solving Based Student Worksheets for Transformation Geometry Course. International Journal on Teaching and Learning Mathematics, 1(1), 13-23.

Marliani, N. (2015). Peningkatan Kemampuan Berpikir Kreatif Matematis Siswa melalui Model Pembelajaran Missouri Mathematics Project (MMP). Formatif: Jurnal Ilmiah Pendidikan MIPA, 5(1), 14-25. https://doi.org/10.30998/formatif.v5i1.166

Mawardi. (2014). Model Desain Pembelajaran Konsep Dasar PKn Berbasis Belajar Mandiri Menggunakan Moodle. Salatiga: Widya Sari Press.

Oktaviani, A. N., \& Nugroho, S. E. (2015). Penerapan Model Creative Problem Solving pada Pembelajaran Kalor untuk Meningkatkan Pemahaman Konsep dan Keterampilan Komunikasi. UPEJ Unnes Physics Education Journal, 4(1), 26-31. https://doi.org/10.15294/upej.v4i1.4733

Puspasari, R. (2019). Pengembangan Buku Ajar Kompilasi Teori Graf dengan Model Addie. Journal of Medives: Journal of Mathematics Education IKIP Veteran Semarang, 3(1), 137. https://doi.org/10.31331/medivesveteran.v3i1.702

Subawa, P. (2016). Standarisasi Dunia Pendidikan. Jurnal Penjaminan Mutu, 2(2), 139. https://doi.org/10.25078/jpm.v2i2.79

Sudijono, A. (2011). Pengantar Evaluasi Pendidikan. Jakarta: PT. Raja Grafindo Persada.

Sukmadinata. (2017). Metode Penelitian Pendidikan. Bandung: PT Remaja Rosdakarya.

Susanto, A. (2017). Pendidikan IPS : Upaya Mengembangkan Kemampuan Berpikir Kreatif. Prosiding Diskusi Panel Pendidikan "Menjadi Guru Pembelajar," April, 23-28.

Yanti, Y. D. dkk. (2016). Pengembangan Lembar Kerja Siswa (LKS) Matematika Berbasis Penemuan Terbimbing untuk Siswa Kelas VIII Sekolah Menengah Pertama pada Materi Kubus, Balok, Prisma dan Limas. Jurnal Mahasiswa Prodi Matematika UPP, 1-8.

Yazdi, M. (2012). E-learning sebagai Media Pembelajaran Interaktif Berbasis Teknologi Informasi. Jurnal Ilmiah Foristek, 2 (1)(1), 143-152.

Yulianti, E. (2019). Pengembangan Lembar Kerja Siswa (LKS) Berbasis Model Pembelajaran Creative Problem Solving Untuk Memfasilitasi Kemampuan Berpikir Kreatif Matematis Siswa SMP Negeri 4 Pekanbaru. Skripsi. Pekanbaru: UIN Sultan Syarif Kasim. 